Jurnal Indonesia Sosial Teknologi: p-ISSN: 2723 - 6609

e-ISSN : 2745-5254

Vol. 2, No. 7 Juli 2021

\title{
FENOMENA PENGAWASAN MARKET CONDUCT DI INDONESIA OLEH OTORITAS JASA KEUANGAN
}

\author{
Anto Prabowo', Mugi Harsono ${ }^{2}$ \\ Universitas Sebelas Maret Surakarta \\ Email: ap.anton.prabowo@gmail.com ${ }^{1}$, mugiharsono_fe@staff.uns.ac.id ${ }^{2}$
}

\begin{abstract}
Abstrak
Badan pengatur standar global telah sepakat tentang perlunya kerangka pengawasan perilaku pasar yang kuat, namun pendalaman terhadap fenomena sebenarnya dari pengawasan market conduct yang telah dilaksanakan oleh Otoritas Jasa Keuangan Indonesia masih sangat kurang. Artikel-artikel penelitian pengawasan market conduct di Indonesia pada umumnya juga jarang menyentuh aspek ekonomi dari fenomena tersebut dengan penekanan analisis yang dominan terhadap dinamika hukum dari fenomena tersebut. Artikel ini menggunakan metode penelitian kualitatif, mmelalui pelaksanaan focus group discussion, literature review dan pemanfaatan Social Fabric Matrix untuk memvisualisasikan bentangan pengawasan market conduct di Indonesia. Tujuan dari artikel ini adalah untuk mengembangkan pengetahuan penelitian di bidang pengawasan market conduct yang dianggap fundamental secara global untuk perlindungan konsumen keuangan, terutama pasca Krisis Keuangan Global 2008. Penelitian ini menggunakan metode metode kualitatif dengan paradigma induktif dan eksploratori. Teknis analisis data tahap studi eksploratori dimulai dengan studi literatur yang dilanjutkan dengan analisis data dalam sesi focus group. Analisis data dilakukan dengan menelaah data hasil wawancara focus group, observasi pelaksanaan sesi focus group, dan dokumentasi sesi tersebut secara deskriptif kualitatif. Hasil dalam penelitian ini terbentuknya struktur regulasi, kerangka organisasi, proses bisnis dan batasan regulasi serta tindakan pengawasan market conduct pada OJK bersumber dari prinsip dan kerangka kerja yang telah ditetapkan dalam Undang-Undang No.21 tahun 2011 tentang Otoritas Jasa Keuangan.
\end{abstract}

Kata kunci: pengawasan; perilaku pasar; perlindungan konsumen jasa keuangan; otoritas jasa keuangan indonesia

\begin{abstract}
The global standard-setting bodies have agreed on the need for a strong market behavior monitoring framework, however, there is still a lack of in-depth study of the actual phenomenon of market conduct supervision that has been implemented by the Indonesian Financial Services Authority. Research articles on market conduct supervision in Indonesia in general rarely touch on the economic aspects of this phenomenon with the dominant emphasis on analysis of the legal dynamics of the phenomenon. This article uses qualitative research methods, through the implementation of focus group discussions, literature reviews and the use of the Social Fabric Matrix to visualize the landscape of market conduct supervision in
\end{abstract}


Indonesia. The purpose of this article is to develop research knowledge in the field of market conduct supervision which is considered globally fundamental for the protection of financial consumers, especially after the 2008 Global Financial Crisis. This research uses qualitative methods with inductive and exploratory paradigms. Technical analysis of data in the exploratory study phase begins with a literature study followed by data analysis in a focus group session. Data analysis was carried out by examining the data from the focus group interviews, observing the implementation of the focus group sessions, and documenting the sessions in a qualitative descriptive manner. The results of this study are the formation of regulatory structures, organizational frameworks, business processes and regulatory boundaries as well as market conduct supervision actions at the OJK are derived from the principles and frameworks that have been stipulated in Law No. 21 of 2011 concerning the Financial Services Authority.

Keywords: Supervision, Market Behavior, Financial Services Consumer Protection, Indonesian Financial Services Authority

\section{Pendahuluan}

Pentingnya perlindungan konsumen sektor jasa keuangan pasca krisis global tahun 2008 yang berdampak signifikan secara sosial dan ekonomi dan pengarusutamaan behavioral economics sebagai landasan dalam penyusunan regulasi perlindungan konsumen telah terpublikasi melalui beberapa hasil penelitian (Lefevre \& Chapman, 2017) Dalam penelitian-penelitian tersebut, diidentifikasikan bias-bias keperilakuan umum yang ditunjukkan individu dalam konteks pengambilan keputusan keuangan, dan penerapan ekonomi perilaku untuk regulasi perlindungan konsumen keuangan yang dapat membantu menyediakan alternatif yang hemat biaya untuk membuat kebijakan perlindungan konsumen sektor jasa keuangan lebih efektif dan bermanfaat bagi kepentingan konsumen (Johnston, Tether, \& Tomlinson, 2015).

Sebelum krisis keuangan global 2008, regulasi sektor jasa keuangan didominasi oleh regulasi prudensial yang mementingkan kesehatan perusahaan keuangan secara individual. Dalam perkembangannya, prinsip perlindungan konsumen sektor jasa keuangan juga menjadi perhatian utama regulator sektor jasa keuangan berbagai negara, khususnya negara-negara G-20. Berpangkal pada biaya ekonomi dan sosial yang besar dari krisis keuangan global, baik ditinjau dari rambatan dampak melalui jalur pasar barang dan tenaga kerja, jalur pasar keuangan dan jalur mekanisme penanganan (coping mechanism) krisis secara privat maupun publik (Otker-Robe \& Podpiera, 2013), lembaga internasional dan lembaga standard-setting regulasi keuangan global mendukung agar implementasi perlindungan konsumen sektor jasa keuangan diterapkan secara lebih universal, khususnya karena kebijakan yang melindungi kepentingan konsumen produk dan jasa keuangan berkontribusi pada peningkatan manajemen risiko oleh rumah tangga, pasar keuangan yang lebih kompetitif, dan stabilitas keuangan yang lebih baik (Board, 2011).

Ketidakcukupan regulasi prudensial untuk mendukung stabilitas sektor keuangan yang terguncang oleh krisis keuangan global tahun 2008 telah diidentifikasi oleh Basel 
Committee on Banking Supervision (BCBS), International Association of Insurance Supervisors (IAIS), dan International Organisation of Securities Commissions (IOSCO). Joint Forum BCBS-IOSCO-IAIS (2010) menyimpulkan diperlukannya penyusunan prinsip yang memadai mengenai market conduct dan perlindungan konsumen yang bermanfaat dan meningkatkan keyakinan konsumen.

Di Indonesia, penerapan perlindungan konsumen sektor jasa keuangan oleh regulator khusus yaitu Otoritas Jasa Keuangan, diatur dalam Undang-undang No.21 tahun 2011 tentang Otoritas Jasa Keuangan (OJK). Peraturan teknis terkait perlindungan konsumen sektor jasa keuangan diatur dalam Peraturan OJK No.1/POJK.07/2013 tentang Perlindungan Konsumen Sektor Jasa Keuangan (POJK No. 1/2013). Namun demikian, dalam perkembangannya, masih diperlukan upaya penyempurnaan terkait kegiatan perlindungan konsumen sektor jasa keuangan tersebut, diantaranya dimana World Bank (2014) menyimpulkan bahwa mandat pengawasan market conduct belum tercermin sepenuhnya pada sistem pengawasan lembaga jasa keuangan di Indonesia. Dalam perkembangannya, OJK melakukan penyempurnaan dalam perlindungan konsumen sektor jasa keuangan, meskipun regulasi khusus mengenai market conduct saat ini belum diatur secara tersendiri.

Penelitian ini bertujuan untuk menyajikan latar belakang yang memadai terhadap topik regulasi dan pengawasan market conduct sektor jasa keuangan Indonesia. Selain itu, mengingat keterbatasan literatur di Indonesia yang mendalami mengenai (i) perlindungan konsumen sektor jasa keuangan dan (ii) kerangka regulasi dan pengawasan market conduct baik dari perspektif ekonomi neoklasik maupun heterodoks, practical knowledge gap dan theoretical gap yang ada akan dijembatani melalui penggunaan instrumen analisis Social Fabric Matrix untuk memperjelas fenomena pengawasan market conduct yang merupakan bentuk perlindungan konsumen sektor jasa keuangan secara ex-ante. Dengan demikian, diharapkan penelitian ini memperkuat pemahaman terhadap pengawasan market conduct di Indonesia sehingga dapat dilakukan penelitian lebih lanjut dari perspektif ilmu ekonomi terhadap fenomena tersebut.

\section{Metode Penelitian}

Mengingat masih terbatasnya penelitian terkait pengawasan market conduct di Indonesia dalam perspektif ekonomi, metode penelitian yang dipergunakan adalah metode kualitatif dengan paradigma induktif dan eksploratori (Jemna, 2016). Dalam perspektif ekonomi heterodoks, fenomena yang diamati tidak dapat dipisahkan dari konteks yang melingkupinya, sehingga setiap analisis yang dilakukan diupayakan menggunakan perspektif system-wide, meskipun dengan dampak hasil kesimpulan dari penelitian ini tidak dapat serta-merta diterapkan pada obyek penelitian yang lain. Selain itu, dikarenakan regulasi market conduct di Indonesia saat ini sedang terus dikembangkan, desain penelitian kualitatif yang memungkinkan dipergunakannya ongoing design dinilai lebih bermanfaat untuk menyesuaikan dengan perkembangan penyusunan peraturan dan penerapan pengawasan market conduct. 
Teknis analisis data tahap studi eksploratori dimulai dengan studi literatur yang dilanjutkan dengan analisis data dalam sesi focus group. Sesi focus group merupakan sarana untuk menjelajahi wilayah yang tidak diketahui (Mishra, 2016), dan dapat menghasilkan pemahaman bersama dan beberapa perspektif topik tertentu jika dilakukan oleh peneliti yang terlatih dan efisien (Dilshad \& Latif, 2013). Analisis data dilakukan dengan menelaah data hasil wawancara focus group, observasi pelaksanaan sesi focus group, dan dokumentasi sesi tersebut secara deskriptif kualitatif. Analisis data dimulai selama proses pengumpulan data, selanjutnya dilakukan reduksi data, penyajian data, dan diakhiri dengan penarikan simpulan hasil wawancara focus group dan verifikasi. Data lapangan yang diperoleh secara deskriptif kualitatif tersebut kemudian dianalisis berdasarkan hasil kajian teori dan digunakan untuk menyusun model.

Focus group discussion terkait pengawasan market conduct dilakukan pada tanggal 10 Juni 2021, yang melibatkan 1 (satu) orang pejabat Otoritas Jasa Keuangan dan 4 (empat) orang pakar dari latar belakang keilmuan ekonomi, hukum dan komunikasi/pemasaran, sejalan dengan bidang ilmu yang berkaitan dengan fenomena pengawasan market conduct. Sesi focus group dipimpin oleh seorang moderator yang independen dan memiliki latar belakang pemahaman terkait topik yang dibahas.

Peneliti menyampaikan overview mengenai teori yang berkaitan dengan fenomena pengawasan market conduct dan kemudian memberikan kesempatan kepada para peserta focus group untuk menyampaikan perspektif berdasarkan latar belakang keilmuan dan pengalamannya. Sesi focus group tersebut juga dihadiri beberapa pemantau (observer) berlatar belakang akademis yang relevan dengan topik pembahasan dan melakukan pemantauan independen terhadap jalannya sesi tersebut. Hasil pelaksanaan focus group discussion menghasilkan data rekaman audiovisual selama 3 jam 7 menit.

\section{Grafik 1. Proses Pelaksanaan Focus Group Discussion}

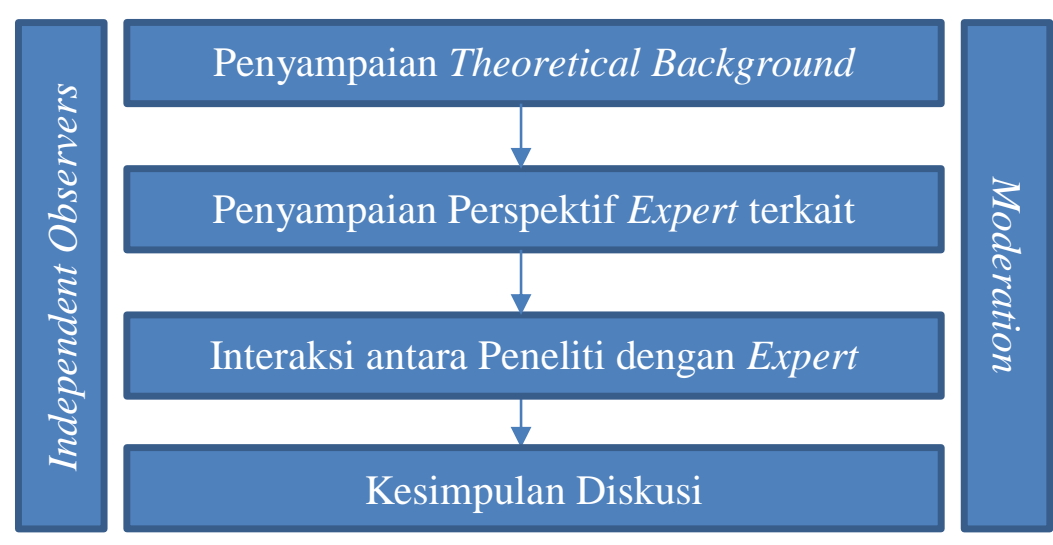

Pelaksanaan Pengumpulan Data Tidak Terstruktur \&

Selain itu, untuk memastikan bahwa pendekatan yang dipergunakan konsisten dan relevan untuk sistem ekonomi dunia nyata serta memenuhi paradigma dalam ekonomi institusional, dipergunakan instrumen analisis Social Fabric Matrix (SFM) yang 
diharapkan dapat memetakan fenomena yang sedang diteliti secara sistematis. SFM adalah "peta atau matriks pengaruh [yang berfungsi sebagai] upaya sistematis untuk mengidentifikasi serangkaian pengaruh yang relevan yang membentuk perilaku suatu sistem. Perangkat ini adalah gambaran dari suatu sistem". Konsisten dengan pendekatan sistem, SFM memungkinkan cara yang tepat untuk berpikir tentang masalah atau isu tertentu, dari mana informasi yang berguna dan solusi yang efisien dapat diperoleh.

(Christiawan \& Arfianto, 2013) menggunakan Social Fabric Matrix untuk menyusun deskripsi mendalam tentang operasi harian Federal Reserve dalam konteks krisis keuangan global tahun 2007-2008, dimana penggunaan kerangka analisis Social Fabric Matrix (SFM) dari operasi Federal Reserve menyajikan komponen utama - norma utama, institusi, teknologi - yang relevan dalam proses penyusunan grounded theory terkait fenomena aktivitas Federal Reserve tersebut. SFM kemudian digunakan untuk analisis sistem normatif untuk menunjukkan artikulasi norma-norma utama melalui subkriteria, aturan, peraturan, dan persyaratan yang menjadi pengaruh yang signifikan pada tindakan komponen institusional yang terlibat dalam operasi Federal Reserve. SFM juga telah dipergunakan sebagai perangkat analisis pelaksanaan fungsi pengelolaan utang negara pada Kementerian Keuangan Amerika Serikat (Treasury Debt Operation) untuk memetakan komponen dari fenomena tersebut.

Dalam penerapannya, peneliti yang menggunakan SFM perlu memetakan institusi di luar fokus penelitian (dalam hal ini Otoritas Jasa Keuangan) untuk mengetahui batasbatas dan institusi-institusi yang berinteraksi dan memberikan pengaruh terhadap jalannya fenomena yang diamati, diantaranya pemangku kepentingan. Menurut (Alemanno, 2015), jika tujuan utama dari regulasi adalah untuk memastikan bahwa regulasi mengutamakan kepentingan publik, hal tersebut hanya dapat diidentifikasi dan didukung oleh pihak-pihak yang terpengaruh oleh regulasi, yaitu pemangku kepentingan, antara lain warga negara, bisnis, konsumen, LSM, sektor publik, perdagangan internasional mitra dan lain-lain (Alemanno, 2015). Untuk kepentingan penelitian ini, institusi di luar Otoritas Jasa Keuangan yang dicantumkan dalam SFM adalah institusi yang utamanya melakukan interaksi sangat intens dengan Otoritas Jasa Keuangan dalam pelaksanaan tugasnya, dalam hal ini adalah Dewan Perwakilan Rakyat dan Presiden dan Kementerian (eksekutif).

\section{Hasil dan Pembahasan}

\section{Perspektif ekonomi neoklasik terkait regulasi perlindungan konsumen sektor jasa keuangan}

Literatur ekonomi neoklasik berfokus pada peran pasar, dan cenderung mengutamakan kontrak antarpihak secara bebas (laissez faire) dibandingkan regulasi, karena regulasi umumnya mahal dan cenderung inefisien. Namun, dalam perkembangannya berbagai krisis keuangan yang terjadi menunjukkan bahwa kegagalan pasar (marketfailure) dapat terjadi dan berbagai asumsi ekonomi neoklasik tidak berlaku pada situasi tersebut. 
Dalam kasus pasar produk dan jasa keuangan, terdapat kemungkinan kegagalan pemenuhan kontrak antara lembaga keuangan dengan. Penyebabnya antara lain konflik keagenan berupa penyediaan saran keuangan yang buruk bagi konsumen, kebangkrutan perusahaan penyedia layanan sebelum dipenuhinya komitmen, ketidaksesuaian antara harapan konsumen dengan produk atau layanan yang diberikan, penipuan atas nama lembaga keuangan, ketidakmampuan untuk menyediakan layanan dalam standar yang diharapkan, kesalahpahaman tentang jenis produk atau atribut risikonya oleh konsumen, dan kecenderungan perilaku yang mengurangi pengambilan keputusan rasional oleh konsumen.

Terdapat beberapa kegagalan pasar yang mendorong kebutuhan regulasi perlindungan konsumen sektor jasa keuangan (Campbell, Jackson, Madrian, \& Tufano, 2010), yaitu kepastian penegakan perlindungan konsumen terkait hak yang tercantum dalam kontrak keuangan, eksternalitas dari perilaku satu individu kepada individu yang lain, biaya pencarian alternatif produk dan kekuatan pasar lembaga yang menyulitkan proses pencarian alternatif tersebut, dan ketiadaan informasi publik yang memadai, yang dapat dikategorikan sebagai asimetri informasi antara lembaga keuangan dengan konsumen.

Di sisi lain, kompleksitas pasar keuangan dalam perkembangannya akan cenderung semakin meningkat dan semakin rentan terhadap asimetri informasi dan masalah keagenan, sehingga self-regulation berupa kontrak dan penegakan hukum oleh pelaku pasar cenderung tidak cukup untuk memastikan pasar berfungsi dengan baik, dan diperlukan intervensi regulasi (Enriques \& Hertig, 2011).

Selain pertimbangan kepentingan konsumen, ekonomi neoklasik juga memperhitungkan dampak regulasi perlindungan konsumen dari sisi lembaga jasa keuangan. Pertama, permasalahan distorsi kompetisi yang timbul pada saat regulasi perlindungan konsumen dapat mengganggu keseimbangan persaingan antar lembaga jasa keuangan. Kedua, biaya fragmentasi rezim regulasi. Regulasi perlindungan konsumen dapat terfragmentasi dalam kewenangan beberapa lembaga regulator, yang menimbulkan biaya tambahan bagi pihak yang diawasi. Permasalahan ini terutama mengemuka pada negara-negara yang menganut model pengawasan twin peak, yang memisahkan pengawasan prudensial dan pengawasan market conduct pada regulator yang berbeda. Selanjutnya, pembentukan regulasi perlindungan konsumen akan menimbulkan biaya administrasi tambahan untuk regulator yang menjalankannya, yang akan diteruskan baik langsung maupun tidak langsung kepada pihak yang diawasi. Di sisi lain, pemenuhan regulasi perlindungan konsumen akan menimbulkan biaya sumber daya manusia dan biaya-biaya lainnya bagi lembaga keuangan. Inovasi untuk menghindari regulator, juga mungkin terjadi pada saat lembaga keuangan melakukan inovasi produk untuk menghindari jangkauan instrumen pengawasan oleh regulator. Yang terakhir, keberadaan rezim regulasi yang ketat dan terperinci ( rigid) dapat menimbulkan moral hazard, dimana rezim regulasi yang kaku, detail, dan protektif dapat menghilangkan tanggung jawab dari pegawai lembaga keuangan dan mengalihkannya kepada pegawai regulator keuangan, sehingga menyebabkan pegawai lembaga keuangan berperilaku ceroboh. 


\section{Perspektif ekonomi heterodoks dalam regulasi perlindungan konsumen sektor jasa keuangan}

(Shiller, 2005) menyimpulkan bahwa dalam berdasarkan analisis sejarahnya ekonomi keperilakuan dan ekonomi institusional merupakan kategori ekonomi heterodoks yang biasanya mengemuka paska krisis ekonomi. Mengemukanya kedua galur ekonomi heterodoks tersebut disebabkan oleh berubahnya arus utama paradigma ekonomi yang semula berfokus pada optimalisasi keuntungan kapitalisme sesuai perspektif neoklasik, beralih menjadi perspektif cenderung mengkritisi dinamika kapitalisme dan ketidaksesuaiannya terhadap realitas masyarakat yang pada umumnya menderita dampak dari krisis ekonomi yang terjadi, khususnya disebabkan gagalnya peran social provisioning dari ekonomi.

Keterkaitan kedua galur ekonomi heterodoks tersebut dan kegunaannya dalam penelitian ini dapat ditinjau dari peran sentral konsep framing sebagai prinsip dasar dari ekonomi keperilakuan (Tversky \& Kahneman, 1980) yang sangat terkait dengan kerangka institusi, dimana perilaku manusia sangat dipengaruhi oleh kerangka referensi (frames of reference). Di sisi lain, struktur institusional yang tersedia di masyarakat merupakan kerangka kerja untuk seluruh pengambilan keputusan manusia Sementara itu, shock perekonomian seperti krisis ekonomi seringkali menimbulkan dampak berupa inovasi institusional (Shiller, 2005), diantaranya institusi baru seperti perlindungan konsumen sektor jasa keuangan dan pengawasan market conduct yang berlandaskan behavioral economics dan sebelumnya belum mengemuka sebelum krisis keuangan global tahun 2008 (Lefevre \& Chapman, 2017).

Dalam perspektif ekonomi perilaku, terdapat beberapa pertimbangan terkait pengaturan perlindungan konsumen. Pertama, dalam penyusunan kontrak jasa keuangan dengan konsumen, lembaga keuangan cenderung memiliki keunggulan yaitu analytical sophistication dan akan mencoba memanfaatkan bias perilaku konsumen untuk memaksimalkan keuntungan melalui asimetri informasi di dalam kontrak, sehingga dibutuhkan regulasi keuangan untuk memitigasi upaya pemanfaatan bias tersebut (Campbell et al., 2010).

Perkembangan pesat sektor jasa keuangan retail (retail finance) pasca krisis keuangan global tahun 2008 ditunjang oleh perkembangan dukungan teknologi. Persaingan pada pasar keuangan kemudian menyediakan berbagai alternatif bagi konsumen. Masalah umum yang kemudian dihadapi konsumen adalah kompleksitas produk dan layanan keuangan yang cukup sulit dipahami, dan pilihan yang banyak. Perbandingan antar produk sulit dilakukan, karena masing-masing produk memiliki fitur khusus, dan struktur harga tidak selalu sepenuhnya transparan (Lefevre \& Chapman, 2017). Selain itu, pilihan finansial biasanya merupakan keputusan penting dalam hidup konsumen yang melibatkan elemen emosional, seperti menginvestasikan tabungan seumur hidup, merencanakan pensiun, dan membeli asuransi yang melibatkan manfaat kematian (Agarwal, Driscoll, Gabaix, \& Laibson, 2009). Di sisi lain, dampak dari keputusan yang dibuat baru muncul dalam jangka panjang, artinya risiko dan 
ketidakpastian dapat memainkan peran yang lebih besar. Konsumen juga akan kesulitan untuk belajar dari pengalaman, karena produk keuangan seringkali merupakan pembelian satu kali (Dambe, Hunt, Iscenko, \& Brambley, 2013).

(Campbell et al., 2010) juga mengemukakan perspektif cognitive limitation konsumen yang mendorong perlunya regulasi, meliputi present-biased preference (Agarwal et al., 2009), keterbatasan kognitif dan buta huruf finansial (Campbell et al., 2010). Konsumen dengan keterbatasan kognitif cenderung untuk tidak percaya terhadap produk keuangan, dan dapat memilih untuk menghindari sama sekali penggunaan produk keuangan. Perspektif lain meliputi kurangnya self-knowledge, dimana konsumen tidak memahami dengan benar kebutuhan diri mereka, diantaranya terkait preferensi dengan waktu yang tidak konsisten (inconsistent time preference) dan keterbatasan kognitif.

Studi yang lebih komprehensif dilakukan oleh Badarinza, (Badarinza, Campbell, \& Ramadorai, 2016) yang mendalami literatur tentang perbandingan situasi keuangan rumah tangga secara internasional berdasarkan statistik dalam neraca rumah tangga untuk 13 negara maju, terutama terkait dengan proporsi tabungan pensiun, investasi pada aset berisiko, utang tanpa jaminan, dan hipotek untuk membahas fitur umum dan perbedaan situasi antarnegara. Metode analisis yang digunakan dalam penelitian tersebut memanfaatkan data administratif berkualitas tinggi dan menggali secara mendalam fitur unik sistem keuangan rumah tangga di berbagai negara dan perubahannya dari waktu ke waktu. Penelitian mereka mengkonfirmasi literatur yang tersedia dalam keuangan rumah tangga yang menunjukkan bahwa beberapa rumah tangga membuat keputusan keuangan yang lebih baik daripada yang lain dan bahwa keputusan keuangan yang buruk dapat memiliki konsekuensi yang signifikan terhadap kesejahteraan seumur hidup rumah tangga.

Dengan demikian, dapat disimpulkan bahwa rasionalitas pelaku ekonomi memiliki keterbatasan, dan terdapat kemungkinan pengambilan keputusan oleh konsumen sektor jasa keuangan bukan merupakan keputusan yang terbaik untuk kepentingan pribadi mereka. Untuk itu, tiga prinsip ekonomi perilaku sangat ditekankan dalam penerapan awal penyusunan regulasi terkait perlindungan konsumen. Pertama, pilihan dipengaruhi oleh kesederhanaan informasi dan jangkauan pilihan yang tersedia. Kedua, konsumen cenderung tertarik pada opsi yang lebih nyaman, terutama opsi default. Ketiga, penekanan (salience) dari pilihan atau atribut dapat mempengaruhi bagaimana pilihan tersebut dipertimbangkan dalam keputusan (Lunn, 2014).

Berdasarkan perspektif historiografi, penerapan upaya dan regulasi perlindungan konsumen biasanya muncul setelah timbulnya permasalahan yang bersifat sistemik, seperti krisis ekonomi (Shiller, 2005). Struktur industri turut berkontribusi pada terciptanya akar permasalahan perlindungan konsumen. Aktivitas perlindungan konsumen yang hanya mengacu pada regulasi lex generalis tersebut di atas cenderung bersifat ex-post dan menganut "imperfectly informed regime". Dengan demikian, konsumen kemungkinan tidak menerima informasi secara penuh mengenai risiko terkait dengan keputusan mereka. Namun, konsumen pada akhirnya tetap dilindungi melalui berbagai mekanisme ex post (sistem peradilan dan alternatif penyelesaian sengketa). 
Dalam perkembangannya, perspektif yang berbeda secara umum telah mulai diterapkan dalam rezim pengaturan perlindungan konsumen sektor jasa keuangan, khususnya terkait perlindungan konsumen secara ex-ante melalui pengawasan market conduct.

\section{Permasalahan Konsumen Jasa Keuangan di Indonesia}

Sejalan dengan penjabaran sumber conduct risk bahwa, kondisi demografi di Indonesia sebagai negara berkembang menimbulkan potensi permasalahan yang belum banyak diulas dalam penelitian-penelitian terkait perlindungan konsumen maupun pengawasan market conduct. Berdasarkan Sensus Penduduk tahun 2020 (BPS, 2020), 25,87\% penduduk Indonesia merupakan generasi Milenial dan 27,94\% merupakan generasi $\mathrm{Z}$ yang memiliki daya beli dan pilihan produk keuangan yang masih terbatas. Sebanyak 9,78\% penduduk merupakan segmen lanjut usia yang berpotensi menghadapi kendala keterbatasan berupa kemampuan kognisi yang menurun dan sulit mengambil keputusan keuangan. Selain itu, dengan porsi $12,23 \%$ penduduk berusia di bawah 18 tahun dan 8,65\% penduduk di atas 18 tahun hidup di bawah garis kemiskinan nasional, ketersediaan akses terhadap produk dan jasa keuangan dengan biaya terjangkau diharapkan dapat meningkatkan peluang pengentasan kemiskinan dan perbaikan taraf hidup (BPS, 2020; Otoritas Jasa Keuangan, 2017a dan 2017b; Republik Indonesia, 2016 dan 2020).

Isu spasial terkait demografi ditunjukkan dari proporsi penduduk yang berdomisili di luar Jawa sebanyak 43,90\% dengan jangkauan akses keuangan yang tidak merata, sedangkan $56,10 \%$ penduduk yang tinggal di Jawa menghadapi situasi dimana terdapat variasi tingkat ketimpangan ekonomi pada tiap-tiap daerah kabupaten/kota namun terdapat akses keuangan yang lebih baik dengan tersedianya jaringan kantor pelaku usaha jasa keuangan yang terkonsentrasi di pulau Jawa. Kendala lain dihadapi oleh 43,3\% penduduk Indonesia yang tinggal di daerah pedesaan dengan akses komunikasi dan fasilitas pendukung yang terbatas (BPS, 2020; OJK 2017a, 2017b, dan 2019).

Di sisi lain, masih terdapat variasi tingkat inklusi dan literasi keuangan yang beragam antar provinsi, yang berpangkal dari berbagai faktor sosio-ekonomis dan geografis. Di sisi lain, tingkat literasi dan inklusi keuangan wilayah perkotaan sebesar $41,41 \%$ dan $83,60 \%$, sedangkan di wilayah pedesaan sebesar $34,53 \%$ dan $68,49 \%$ (OJK, 2019).

Survei OJK tersebut mengungkap bahwa inklusi dan literasi keuangan di Indonesia masih didominasi oleh sektor perbankan (OJK, 2019), meskipun seharusnya kebutuhan konsumen sesuai life cycle-nya dapat lebih tepat dilayani oleh berbagai macam produk keuangan yang disediakan oleh sektor jasa keuangan lainnya (Badarinza et al., 2016). Dengan demikian, potensi kerjasama antar pelaku usaha jasa keuangan perbankan dengan pasar modal dan industri keuangan non-bank lainnya (antara lain asuransi) seperti kanal distribusi bancassurance dan pemasaran produk pasar modal melalui perbankan juga dapat memunculkan kompleksitas permasalahan perlindungan konsumen sektor jasa keuangan. 
Sementara itu, perkembangan teknologi di sektor jasa keuangan yang mendorong inovasi dan perkembangan strategi lembaga keuangan menimbulkan kecenderungan strategi pemasaran dan pelayanan konsumen yang mengurangi level playing field antara pelaku usaha jasa keuangan dan konsumen (OJK, 2017a dan 2017b). Dengan tingkat penetrasi pengguna internet 2019-2020 yang mencapai 73,7\%, dan meningkat dari posisi 2018 sebesar 64,8\% (APJII, 2020), layanan keuangan digital akan mengalami pengarusutamaan dan mengambil pangsa pasar yang semakin besar. Dengan demikian, potensi permasalahan market conduct dari pelaku usaha jasa keuangan yang menyediakan layanan berbasis internet dan digital financial services dengan teknik pemasaran digital berlandaskan data mengenai preferensi konsumen, bauran produk yang semakin beragam dan penggunaan user interface dan algoritma pada aplikasi digital yang berpotensi eksploitatif dan mengganggu privasi konsumen akan semakin mengemuka di kemudian hari.

Dalam perkembangannya, aktivitas pengawasan market conduct yang dilaksanakan OJK selama periode 2016 sampai dengan 2020 meliputi aktivitas market intelligence, thematic surveillance dan kegiatan perlindungan konsumen (OJK, 2020). OJK telah melakukan pemantauan iklan sektor jasa keuangan dalam kurun waktu tersebut, dengan statistik pelanggaran sebagaimana tercantum dalam tabel 1 .

\section{Tabel 1. Social Fabric Matrix dari Pengawasan Market Conduct di} Indonesia oleh Otoritas Jasa Keuangan

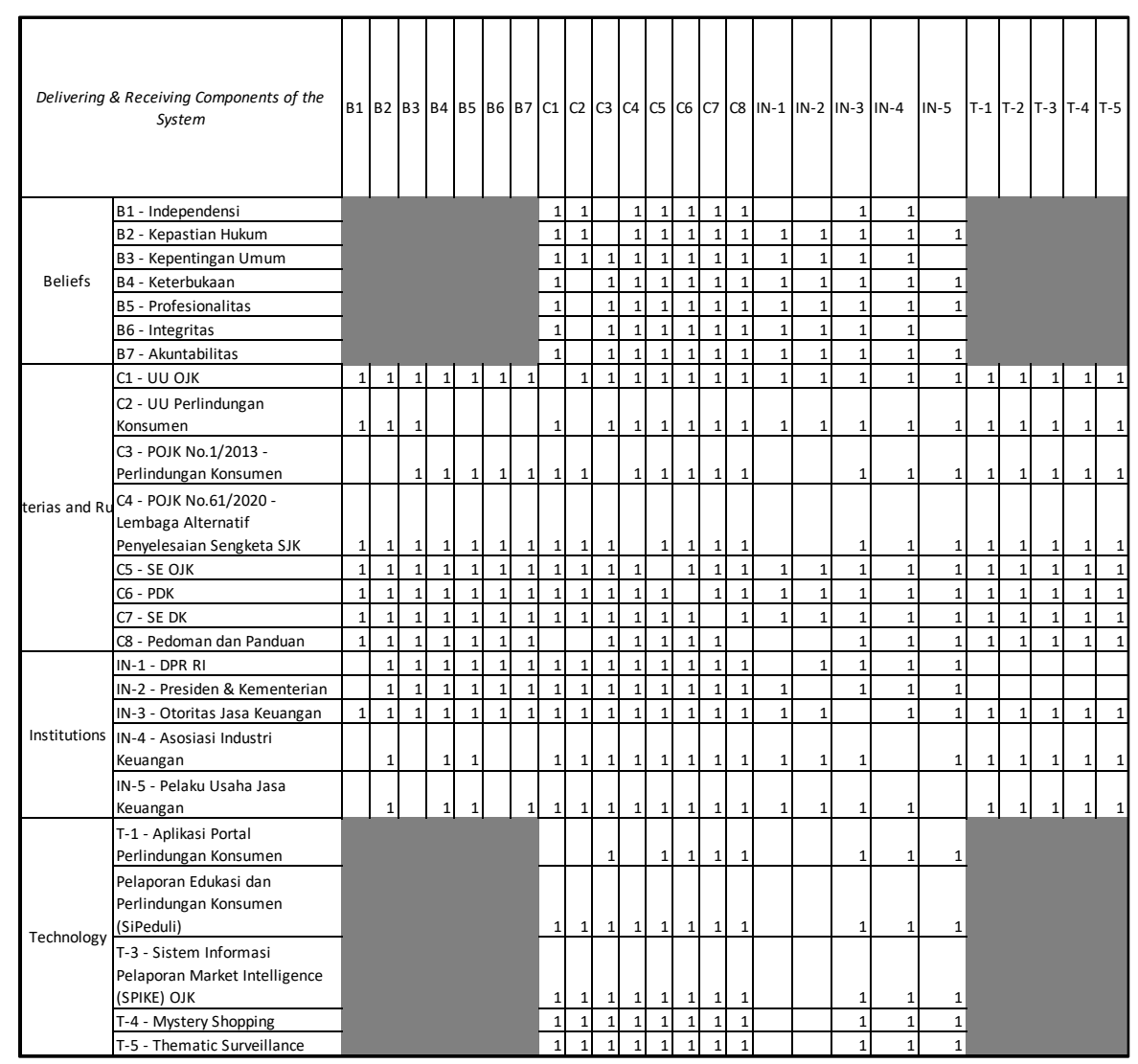




\section{Hasil Analisis Social Fabric Matrix}

Berdasarkan telaah literatur, content analysis dan hasil focus group discussion yang telah dilaksanakan, penyusunan SFM dilakukan dengan beberapa tahap, yaitu (i) penyusunan konvergensi social beliefs yang menjadi alasan munculnya fenomena yang diamati. Dalam hal ini, segenap pembahasan di atas telah mencakup beberapa prinsip terkait perlindungan konsumen maupun pengawasan market conduct yang perlu dikaitkan dengan social belief dari economic actor yang menimbulkan fenomena tersebut (dalam hal ini Otoritas Jasa Keuangan).

Untuk memastikan social beliefs yang dicantumkan dalam SFM merupakan nilainilai yang paling relevan dengan fenomena, dilakukan proses analisis content review terhadap dokumen-dokumen legislasi, regulasi maupun publikasi resmi Otoritas Jasa Keuangan agar dapat disimpulkan social beliefs yang paling relevan dengan permasalahan yang sedang diamati. Berdasarkan tabel 2 di bawah ini, disimpulkan bahwa asas-asas yang tercantum dalam Undang-Undang No. 21 tahun 2011 tentang Otoritas Jasa Keuangan merupakan social beliefs dalam pelaksanaan pengawasan market conduct yang paling relevan dan dapat menjembatani segenap prinsip yang menjadi landasan dalam konteks penelitian. Asas-asas tersebut meliputi independensi, kepastian hukum, kepentingan umum, keterbukaan, profesionalitas, integritas dan akuntabilitas.

Tabel 2. Konvergensi Social Beliefs dari Prinsip-prinsip terkait Perlindungan Konsumen Sektor Jasa Keuangan dengan Prinsip dalam Legislasi dan Regulasi Terkait

\begin{tabular}{ccccc}
\hline UU No.30 tahun & UU No. 8 tahun & UU No. 21 & G-20 High Level & POJK \\
2014 tentang & 1999 tentang & tahun 2011 & Principles on & No.1/POJK.07/2013 \\
Administrasi & Perlindungan & tentang Otoritas & Financial & tentang \\
Pemerintahan & Konsumen & Jasa Keuangan & Consumer & Perlindungan \\
& & & Protection & Konsumen
\end{tabular}

\begin{tabular}{|c|c|c|c|c|}
\hline Ketidakberpihakan & Keseimbangan & Independensi & Competition & \\
\hline Kepastian Hukum & $\begin{array}{c}\text { Kepastian } \\
\text { Hukum }\end{array}$ & $\begin{array}{c}\text { Kepastian } \\
\text { Hukum }\end{array}$ & $\begin{array}{c}\text { Legal, Regulatory } \\
\text { and Supervisory } \\
\text { Framework }\end{array}$ & \\
\hline $\begin{array}{l}\text { Kepentingan } \\
\text { Umum } \\
\text { Kemanfaatan }\end{array}$ & $\begin{array}{c}\text { Keadilan } \\
\text { Manfaat } \\
\text { Keamanan dan } \\
\text { keselamatan } \\
\text { konsumen }\end{array}$ & $\begin{array}{l}\text { - Kepentingan } \\
\text { Umum }\end{array}$ & $\begin{array}{l}\text { - Equitable and } \\
\text { Fair Treatment } \\
\text { of Consumers, } \\
\text { - Protection of } \\
\text { Consumer } \\
\text { Data and } \\
\text { Privacy, } \\
\text { - Protection of } \\
\text { Consumer } \\
\text { Assets against }\end{array}$ & $\begin{array}{c}\text { perlakuan yang adil; } \\
\text { kerahasiaan dan } \\
\text { keamanan } \\
\text { data/informasi } \\
\text { Konsumen }\end{array}$ \\
\hline
\end{tabular}


Fenomena Pengawasan Market Conduct di Indonesia oleh Otoritas Jasa Keuangan

\begin{tabular}{|c|c|c|c|c|}
\hline $\begin{array}{l}\text { UU No.30 tahun } \\
2014 \text { tentang } \\
\text { Administrasi } \\
\text { Pemerintahan }\end{array}$ & $\begin{array}{l}\text { UU No. } 8 \text { tahun } \\
1999 \text { tentang } \\
\text { Perlindungan } \\
\text { Konsumen }\end{array}$ & $\begin{array}{c}\text { UU No. } 21 \\
\text { tahun } 2011 \\
\text { tentang Otoritas } \\
\text { Jasa Keuangan }\end{array}$ & $\begin{array}{c}\text { G-20 High Level } \\
\text { Principles on } \\
\text { Financial } \\
\text { Consumer } \\
\text { Protection }\end{array}$ & $\begin{array}{c}\text { POJK } \\
\text { No.1/POJK.07/2013 } \\
\text { tentang } \\
\text { Perlindungan } \\
\text { Konsumen }\end{array}$ \\
\hline & & & $\begin{array}{l}\text { Fraud and } \\
\text { Misuse, } \\
\text { - Financial } \\
\text { Education and } \\
\text { Awareness }\end{array}$ & \\
\hline Keterbukaan & & Keterbukaan & $\begin{array}{l}\text { Disclosure and } \\
\text { Transparency }\end{array}$ & transparansi; \\
\hline $\begin{array}{c}\text { Kecermatan } \\
\text { Pelayanan yang } \\
\text { Baik }\end{array}$ & & Profesionalitas & $\begin{array}{c}\text { Responsible } \\
\text { Business Conduct } \\
\text { of Financial } \\
\text { Services Providers } \\
\text { and Authorized } \\
\text { Agents, }\end{array}$ & keandalan; \\
\hline $\begin{array}{c}\text { Tidak } \\
\text { Menyalahgunakan } \\
\text { Wewenang }\end{array}$ & & Integritas & $\begin{array}{l}\text { Complaints } \\
\text { Handling and } \\
\text { Redress }\end{array}$ & $\begin{array}{c}\text { penanganan } \\
\text { pengaduan serta } \\
\text { penyelesaian } \\
\text { sengketa Konsumen } \\
\text { secara sederhana, } \\
\text { cepat, dan biaya } \\
\text { terjangkau. }\end{array}$ \\
\hline
\end{tabular}

\section{Akuntabilitas Role of Oversight \\ Bodies}

Sumber: Republik Indonesia (1999, 2011, dan 2014), OECD (2013), dan OJK (2013), dianalisis lebih lanjut oleh penulis

Hasil konvergensi social beliefs tersebut kemudian dijadikan sebagai key component dalam SFM yang disusun. Kemudian keterkaitannya dengan komponen sistem lainnya yaitu criterias and rules, institutions, dan technology akan menjadi penjelas visualisasi sistematik dari fenomena yang diteliti. Pemahaman social beliefs yang jelas akan membantu mempermudah memahami keterkaitan antara beberapa komponen criterias dan rules yang mendefinisikan regulatory boundaries dari fenomena pengawasan market conduct oleh Otoritas Jasa Keuangan pada grafik berikut.

\section{Grafik 2. Konstelasi Criterias and Rules terkait Pengawasan Market Conduct}




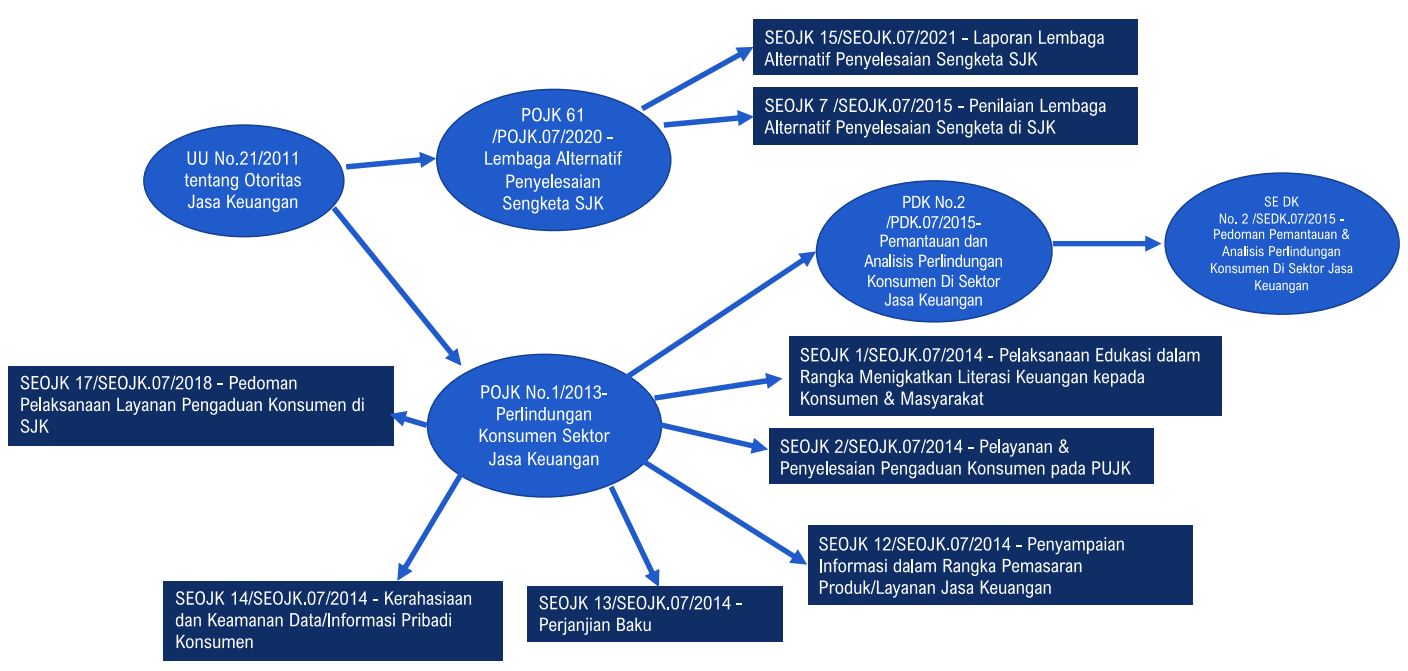

Hasil analisis Social Fabric Matrix berupa penetapan prinsip umum untuk memahami pengawasan market conduct oleh Otoritas Jasa Keuangan, meliputi social beliefs dan criteria and rules yang melandasi kegiatan pengawasan market conduct tersebut, rancangan institusional dan konteks yang melatarbelakangi kegiatan pengawasan market conduct tersebut, termasuk institusi lain di luar Otoritas Jasa Keuangan yang memberikan masukan maupun menerima dampak dari pelaksanaan kegiatan pengawasan market conduct tersebut.

\section{Kesimpulan}

Berdasarkan kajian yang telah dilakukan dan dijabarkan pada bab-bab sebelumnya berkaitan dengan Fenomena Pengawasan Market Conduct Di Indonesia oleh Otoritas Jasa Keuangan, maka dalam penelitian ini dapat ditarik kesimpulan yaitu dari sisi fenomena, terbentuknya struktur regulasi, kerangka organisasi, proses bisnis dan batasan regulasi serta tindakan pengawasan market conduct pada OJK bersumber dari prinsip dan kerangka kerja yang telah ditetapkan dalam Undang-Undang No.21 tahun 2011 tentang Otoritas Jasa Keuangan.

Penelitian ini dapat menelusuri latar belakang teoritis dari penerapan pengawasan market conduct. SFM yang telah disusun dengan demikian dapat menangkap cakupan keterkaitan dari berbagai komponen dalam sistematika fenomena pengawasan market conduct, sehingga dapat memperjelas fenomena yang sedang diamati. Ke depannya, penyesuaian dari konstruksi sistem tersebut tentunya akan berakar pada penyelarasan social beliefs dan disesuaikan juga pada criteria dan rules yang akan mengatur dinamika aktor dan lingkungan yang melingkupi institusi tersebut. Secara pragmatis, dengan demikian pngembangan pengawasan market conduct ke depan dengan mengacu pada legislasi tersebut akan cukup terbatas sesuai perimeter regulatory boundaries yang diatur dalam Undang-Undang No.21 tahun 2011. Penyesuaian regulatory boundaries tersebut membutuhkan pertimbangan cost and benefit analysis yang menyeimbangkan kepentingan konsumen dengan kepentingan perusahaan yang diawasi. 
Tanpa penyesuaian regulatory boundaries, efektivitas pengawasan market conduct ke depannya bergantung pada kecukupan harmonisasi dengan ruang lingkup dan kewenangan pengawasan prudensial sesuai UU OJK. Berdasarkan hal tersebut, maka saran yang dapat diberikan pada penelitian ini adalah diperlukan pengamatan yang lebih terperinci dan mendalam antara diskursus legal dalam perlindungan konsumen jasa keuangan dan pengawasan market conduct dengan aspek ekonomi dari fenomena tersebut. Penggunaan paradigma legal and economics analysis kemungkinan dapat menjembatani lebih lanjut aspek eksploratori terhadap fenomena tersebut. Dengan demikian, hal ini akan memperkaya dan mendukung penggunaan perangkat analisis Social Fabric Matrix dan perspektif heterodoks diharapkan dapat menjembatani penelitian multidisiplin selanjutnya terkait pengawasan market conduct yang sejalan dengan perspektif legal-ekonomi dalam institutional economics dan perspektif sosiopsikologis dalam behavioral economics, serta memungkinkan pemanfaatan literatur penelitian hukum dan bidang sosial lainnya untuk memperdalam analisis terkait fenomena pengawasan market conduct oleh Otoritas Jasa Keuangan di Indonesia.

Sebagai sebuah penelitian kualitatif, hasil analisis dan simpulan dari penelitian ini hanya dapat berlaku bagi penelitian ini dan sejauh ini belum dapat digeneralisasi ke situasi yang lebih luas tanpa proses kuantifikasi yang memadai. Penggunaan metode penelitian yang memfasilitasi hal tersebut akan dapat memperjelas pengamatan terhadap fenomena dan memperkuat validitas dari penelitian tersebut. 


\section{Bibliografi}

Agarwal, Sumit, Driscoll, John C., Gabaix, Xavier, \& Laibson, David. (2009). The age of reason: Financial decisions over the life cycle and implications for regulation. Brookings Papers on Economic Activity, 2009(2), 51-117.

Alemanno, Alberto. (2015). Stakeholder engagement in regulatory policy. Regulatory Policy Outlook, OECD Publishing.

Badarinza, Cristian, Campbell, John Y., \& Ramadorai, Tarun. (2016). International comparative household finance. Annual Review of Economics, 8, 111-144.

Board, Financial Stability. (2011). Consumer finance protection with particular focus on credit. Basel: Financial Stability Board.

Campbell, John Y., Jackson, Howell E., Madrian, Brigitte C., \& Tufano, Peter. (2010). The regulation of consumer financial products: an introductory essay with four case studies.

Christiawan, Nicolaus Gerry, \& Arfianto, Erman Denny. (2013). Interbank Contagious: Sistemik Market Risk Kasus Pada Perbankan Indonesia 2002-2012. Fakultas Ekonomika dan Bisnis.

Dambe, Kristine, Hunt, Stefan, Iscenko, Zanna, \& Brambley, Will. (2013). Applying behavioural economics at the Financial Conduct Authority. FCA Occasional Paper, (1).

Dilshad, Rana Muhammad, \& Latif, Muhammad Ijaz. (2013). Focus group interview as a tool for qualitative research: An analysis. Pakistan Journal of Social Sciences (PJSS), 33(1).

Enriques, Luca, \& Hertig, Gérard. (2011). Improving the governance of financial supervisors. European Business Organization Law Review (EBOR), 12(3), 357-378.

Jemna, Ligia Muntean. (2016). Qualitative and mixed research methods in economics: the added value when using qualitative research methods. Journal of Public Administration, Finance and Law, (09), 154-167.

Johnston, Kirsty, Tether, Christine, \& Tomlinson, Ashley. (2015). Financial Product Disclosure: Insights from Behavioural Economics. Ministry of Business Innovation \& Employment, Hīkina Whakatutuki.

Lefevre, Anne Francoise, \& Chapman, Michael. (2017). Behavioural economics and financial consumer protection.

Lunn, P. (2014). Regulatory Politics and Behavioural Economics. OECD Publishing, http://www. keepeek. com/Digital-Asset-Management/oecd .... 
Fenomena Pengawasan Market Conduct di Indonesia oleh Otoritas Jasa Keuangan

Mishra, Lokanath. (2016). Focus group discussion in qualitative research. Techno Learn, $6(1), 1$.

Otker-Robe, Inci, \& Podpiera, Anca Maria. (2013). The social impact of financial crises: evidence from the global financial crisis. World Bank Policy Research Working Paper, (6703).

Shiller, Robert J. (2005). Behavioral economics and institutional innovation. Available at SSRN 671024

Tversky, Amos, \& Kahneman, Daniel. (1980). The framing of decisions and the rationality of choice. STANFORD UNIV CA DEPT OF PSYCHOLOGY. 